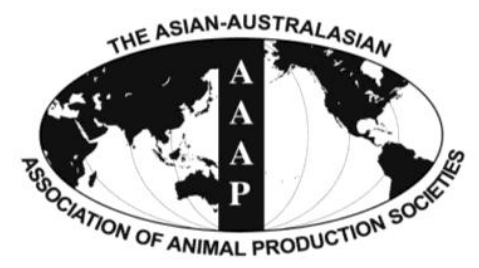

Asian-Aust. J. Anim. Sci.

Vol. 26, No. 2 : 287-294 February 2013

http://dx.doi.org/10.5713/ajas.2012.12438

www.ajas.info

pISSN 1011-2367 elSSN 1976-5517

\title{
Antioxidant Activities of Achyranthes japonica Nakai Extract and Its Application to the Pork Sausages
}

\author{
J. H. Park ${ }^{1}$, S. N. Kang ${ }^{1}$, D. Shin ${ }^{2}$, I. C. Hur ${ }^{3}$, I. S. Kim ${ }^{3}$ and S. K. Jin ${ }^{3} *$ \\ ${ }^{1}$ Swine Science and Technology Center, Gyeongnam National University of Science and Technology, \\ Jinju 660-758, Korea
}

\begin{abstract}
Influence of Achyranthes japonica Nakai Extract (AJNE) on properties of pork sausages were studied in the present investigation. AJNE was added to sausages alone or in combination with ascorbic acid to obtain a comparative analysis on properties of control and ascorbic acid added-sausages. Results showed that addition of $0.05 \%$ AJNE led to a decrease in color $\mathrm{L}^{*}$ and whiteness (W), and an increase in color $\mathrm{b}^{*}$ of pork sausage samples $(\mathrm{p}<0.05)$. Although color $\mathrm{a}$ * of pork sausages containing AJNE was not significantly different, ascorbic acid added-sausages were highest amongst other treatments $(\mathrm{p}<0.05)$. Sausages containing AJNE had lower non-heme iron values and peroxide value (POV) than control sausages $(\mathrm{p}<0.05)$; however, high nitrosomyoglobin content was observed in AJNE added-sausages $(\mathrm{p}<0.05)$. Ascorbic acid led to a decrease in residual nitrite concentration of sausages $(\mathrm{p}<0.05)$, but no difference was found in AJNE added-sausages. Free radical scavenging analysis showed that AJNE did not affect 1,1-diphenyl -2-picrylhydrazyl (DPPH) activity of sausages, whereas ascorbic acid added-sausages showed relatively higher activity among the samples $(\mathrm{p}<0.05)$. Addition of AJNE had no influence on texture properties of sausages. In sensory evaluation, AJNE treatment had significant effects on color ( $\mathrm{p}<0.05$ ), but no significant effects on aroma, flavor, springiness, juiciness, and overall acceptability. In conclusion, the addition of AJNE, as a natural supplement may offer natural antioxidants for pork sausages, and appears to be particularly effective in inducing changes in non-heme iron concentration, POV value and nitrosomyglobin content. (Key Words: Achyranthes japonica Nakai Extract, Peroxide Value, Pork Sausage, Nitrosomyoglobin, Sensory Evaluation)
\end{abstract}

\section{INTRODUCTION}

Natural food additives derived from herbs and spices have been recognized and used for centuries in food preservation. In recent years, the increasing interest of consumers for natural foods or foods free from artificial chemicals has raised the demand for meat products. Therefore, functional properties of numerous plant extracts have been investigated, and many herbs, spices, and their extracts have been proven to possess high antimicrobial and antioxidant activity with respect to their functional properties in meat products (Wu et al., 2006; Kong et al., 2007; Wojdylo et al., 2007; Rounds et al., 2012). The most

\footnotetext{
* Corresponding Author: Sang Keun Jin. Tel: +82-55-751-3584, Fax: +82-55-751-3689, E-mail: skjin@gntech.ac.kr

${ }^{2}$ Department of Animal Science, Chonbuk National University, Jeonju 561-756, Korea.

${ }^{3}$ Department of Animal Resources Technology, Gyeongnam National University of Science and Technology, Jinju 660-758, Korea.

Submitted Aug. 13, 2012; Accepted Oct. 15, 2012; Revised Nov. 7, 2012
}

important of these bioactive plants substances are flavonoids, alkaloids, tannins, saponins, glycosides, phenolic compounds and essential oils (Cowan, 1999; Torres et al., 2002; Medina et al., 2003).

The use of plant extracts is an effective way to minimize lipid oxidation in meat products, thus maintaining nutritional quality (Tanabe et al., 2002). Some studies have demonstrated that shelf-life and meat quality can be improved by using natural antioxidants during storage of meat products (Chouliara et al., 2007; Martin-Diana et al., 2008). Therefore, plant extracts are important ingredients of the quality of meat products because it affects the color, flavor, texture, and nutritional value of these foods.

Achyranthes japonica Nakai (AJN) is a perennial herb that has a wide distribution in East Asia including Korea, China, and Japan and mainly used as a medicinal plant (Jung et al., 2007). AJN has various physiological effects including the control of blood circulation, the removal of extravasated blood, and the inteneration of joint actions in humans and experimental animals (Marcone et al., 2003). The root of AJN contains various active components, 
including phytoecdysteroid, saponin, polysaccharide, 20hydroxyecdysone, and inokosterone and has also been demonstrated to exhibit the highest inhibitory effect against Clostridium difficile amongst various herb extracts (Jung et al., 2007). Although plant extracts induced changes in physicochemical properties with apparent effect on meat quality have widely been reported, the effect of AJNE on the quality of sausages has not been studied yet.

Thus, this study was performed to investigate the potential possibility of antioxidant by measuring meat color, non-heme iron, POV, residual nitrite, nitrosomyoglobin, $\mathrm{DPPH}$, texture properties and sensory evaluation.

\section{MATERIALS AND METHODS}

\section{Preparation of Achyranthes japonica Nakai extract}

Air dried AJN roots were purchased from local herbal market. After grinding for $1 \mathrm{~min}$, AJN powder was boiled in distilled water (1:10) for $3 \mathrm{~h}$. The mixture was then filtered, and evaporated in a vacuum at a temperature of $70^{\circ} \mathrm{C}$ using a rotary evaporator (RW-0525G, Heidolph, Germany). The extract was stored at $4^{\circ} \mathrm{C}$ until used.

\section{Total phenol content}

Total phenol content in sample extracts was determined spectrophotometrically according to the Folin-Ciocalteu method (Singleton and Rossi, 1965). Because catechin is one of the polyphenol compounds, total phenol content of extract from Achyranthes japonica Nakai was expressed as microgram catechin equivalents/milligram extract ( $\mu \mathrm{g}$ $\mathrm{CE} / \mathrm{mg}$ ). Typically, $150 \mathrm{ml}$ of sample at a concentration of 1 $\mathrm{mg} / \mathrm{ml}, 2.4 \mathrm{~L}$ of deionized water, and $150 \mathrm{ml}$ of $0.25 \mathrm{~N}$ Folin-Ciocalteu reagents were combined in a plastic vial, and then mixed well using a vortex mixer. The mixture was allowed to react for $3 \mathrm{~min}$, and then $300 \mathrm{ml}$ of $1 \mathrm{~N} \mathrm{Na}_{2} \mathrm{CO}_{3}$ solution was added, and mixed well. The solution was incubated at ambient room temperature $\left(23^{\circ} \mathrm{C}\right)$ in a dark place for $2 \mathrm{~h}$. The absorbance was measured at $725 \mathrm{~nm}$ using a spectrophotometer (Hewlett Packard 8452A, Diode Array, Santa Clara, CA, USA). Additional dilution was done if the absorbance value measured was over the linear range of the standard curve $\left(\mathrm{Y}=0.0016 \mathrm{X}+0.0424, \mathrm{R}^{2}=\right.$ 0.9999).

\section{Total flavonoid content}

Total flavonoid content was determined using the method of Chun et al. (2003) with minor modifications. Exactly, $0.25 \mathrm{ml}$ of sample $(1 \mathrm{mg} / \mathrm{ml})$ was added to a tube containing $1 \mathrm{ml}$ of double-distilled water. Subsequently, $0.075 \mathrm{ml}$ of $5 \% \mathrm{NaNO}_{2}, 0.075 \mathrm{ml}$ of $10 \% \mathrm{AlCl}_{3}$ and $0.5 \mathrm{ml}$ of $1 \mathrm{M} \mathrm{NaOH}$ were added at 0,5 and $6 \mathrm{~min}$, sequentially. Finally, the volume of the reacting solution was made up to $2.5 \mathrm{ml}$ with double-distilled water. The absorbance of the solution was recorded at a wavelength of $410 \mathrm{~nm}$, and was detected using the Ultrospec 2100 pro spectrophotometers. Quercetin, a ubiquitous flavonoid present in many plant extracts, was used as a standard to quantify the total flavonoid content of water extract. Results were expressed as microgram quercetin equivalents/milligram extract ( $\mu \mathrm{g}$ $\mathrm{QE} / \mathrm{mg})$.

\section{Experimental design and sausage processing}

Pork loins were obtained from a local slaughter house $24 \mathrm{~h}$ post mortem. The meat was ground after removal of visible fat and connective tissue. Experimental sausages were manufactured under the conditions described by Jin et al. (2002). Four treatments of boiled pork sausages were prepared (Table 1). The control (CON) was prepared with the addition of sodium nitrite without AJNE or ascorbic acid. The other three treatments were prepared with $0.05 \%$ ascorbic acid (T1), $0.05 \%$ AJNE (T2), and $0.025 \%$ ascorbic acid plus $0.025 \%$ AJNE (T3). All the samples were stored in refrigerator at $10^{\circ} \mathrm{C}$ for $7 \mathrm{~d}$.

\section{Evaluation of sausage meat color}

Color properties (CIE L*, $\mathrm{a}^{*}$ and $\mathrm{b}^{*}$ ) of cooked pork sausages were evaluated by Minolta colorimeter (CR-300, Tokyo, Japan) calibrated against a white plate $\left(\mathrm{L}^{*}=93.5, \mathrm{a}^{*}\right.$ $=0.3132$, and $\left.b^{*}=0.3198\right)$ at $7 \mathrm{~d}$ storage period. The $\mathrm{W}$ (whiteness) was calculated using the following formula: $\mathrm{L}^{*}$ $3 b^{*}$ (Park, 2005). Three replicate measures were performed on each sample.

\section{Determination in non-heme iron concentration}

Non-heme iron concentration in sausages was determined by following the modified method of Carter (1971). Four gram of ground meat and $12 \mathrm{ml}$ of deionized

Table 1. The sausage formulation as affected by ascorbic acid and AJNE

\begin{tabular}{|c|c|c|c|c|}
\hline \multirow{2}{*}{ Ingredients (\%) } & \multicolumn{4}{|c|}{ Treatments } \\
\hline & $\mathrm{CON}$ & $\mathrm{T} 1$ & $\mathrm{~T} 2$ & $\mathrm{~T} 3$ \\
\hline Lean pork loin & 72.40 & 72.40 & 72.40 & 72.40 \\
\hline Pork back fat & 11.20 & 11.20 & 11.20 & 11.20 \\
\hline Ice & 13.80 & 13.75 & 13.75 & 13.75 \\
\hline Salt & 1.39 & 1.39 & 1.39 & 1.39 \\
\hline Sodium nitrite & 0.01 & 0.01 & 0.01 & 0.01 \\
\hline Phosphate & 0.24 & 0.24 & 0.24 & 0.24 \\
\hline Sugar & 0.50 & 0.50 & 0.50 & 0.50 \\
\hline $\mathrm{MSG}^{1}$ & 0.06 & 0.06 & 0.06 & 0.06 \\
\hline Seasoning $^{2}$ & 0.40 & 0.40 & 0.40 & 0.40 \\
\hline L-ascorbic acid & - & 0.05 & - & 0.025 \\
\hline AJNE & - & - & 0.05 & 0.025 \\
\hline Total & 100 & 100 & 100 & 100 \\
\hline
\end{tabular}


distilled water were added to a disposable test tube. The sample mixture was vortexed, and $1 \mathrm{ml}$ of $11.3 \%$ TCA was added. After centrifugation at 4,000 rpm for $15 \mathrm{~min}, 2 \mathrm{ml}$ of supernatant was mixed with $0.8 \mathrm{ml}$ of $10 \%$ ammonium acetate and $0.2 \mathrm{ml}$ of ferroin color reagent. Iron concentrations of the supernatant were determined by spectrophotomer and non-heme iron concentration was calculated by subtracting the value of heme iron from total iron.

\section{Determination of peroxide value}

The peroxide value (POV) was determined as described in the AOAC (2000). Typically, $5 \mathrm{~g}$ of sample was weighed in a $50 \mathrm{ml}$ glass tube, and to this $30 \mathrm{ml}$ of acetic acidchloroform mixture $(3: 2 \mathrm{v} / \mathrm{v})$ was added. After incubation at $60^{\circ} \mathrm{C}$ for $5 \mathrm{~min}$ in a water bath, the mixture was filtered using No. 1 Whatman filter paper. Subsequently, $0.5 \mathrm{ml}$ of potassium iodide solution was added to the filtrate, which was further analyzed using an automatic titrator equipped with $\mathrm{pH}$ meter and stirrer. The titration was allowed to run against standard solution of $0.1 \mathrm{~N}$ sodium thiosulfate. POV was expressed as milliequivalent (meq) of active oxygen per $\mathrm{kg}$ of sausage.

\section{Determination of nitrite concentration}

Residual nitrite concentration was determined by a spectrophotometric method (AOAC, 2000). Typically, $5 \mathrm{~g}$ sample of minced sausage was transferred to a $500 \mathrm{ml}$ volumetric flask containing $40 \mathrm{ml}$ of hot water $\left(80^{\circ} \mathrm{C}\right)$, and the volume was made up to $300 \mathrm{ml}$ with hot water. After thorough mixing, the flask was heated in a steam bath for 2 $\mathrm{h}$ before adding more water to bring the volume to $500 \mathrm{ml}$. The mixture was then filtered $(0.45 \mu \mathrm{m}$ filter $)$, and an aliquot $(45 \mathrm{ml})$ was transferred to a $50 \mathrm{ml}$ volumetric flask together with $2.5 \mathrm{ml}$ of sulphanilamide (SUL), and set aside for $5 \mathrm{~min}$; then $2.5 \mathrm{ml}$ of N-ethylenediamine dihydrochloride (NED) was added. After waiting for 1.5 min for color development, the absorbance was determined at $540 \mathrm{~nm}$ against a blank comprising of $45 \mathrm{ml}$ of water, 2.5 $\mathrm{ml}$ of SUL and $2.5 \mathrm{ml}$ of NED.

\section{Determination of nitrosomyoglobin concentration}

Nitrosomyoglobin concentration in the sausages was determined according to the method of Bozkurt and Erkmen (2004). Typically, $10 \mathrm{~g}$ of minced sample was added to solvent mixture of $40 \mathrm{ml}$ of acetone and $3 \mathrm{ml}$ of water, mixed and allowed to stand for $5 \mathrm{~min}$. After filtration and centrifugation for $5 \mathrm{~min}$ at $1,790 \times g$, the absorbance value was read at $540 \mathrm{~nm}$ with respect to a blank solution. The result was expressed as $\mathrm{mg} / \mathrm{kg}$ nitroso haem pigments.

\section{DPPH radical scavenging activity}

The DPPH scavenging activity of sausages was measured using a spectrophotometer (Akowuah et al., 2005). A diluted extract of concentration of $0.15 \mathrm{ml}$ was added to $0.9 \mathrm{ml}$ of the methanolic DPPH solution $(0.1 \mathrm{mM})$. After 10 min., the absorbance of the solution was measured at 517 $\mathrm{nm}$. Pure methanol was used as the control. Percentage of DPPH scavenging activity (\% SA) was calculated from the equation (1-(absorbance of extract/absorbance of control) $) \times 100$.

\section{Texture property}

Mechanical properties of sausage samples $(1.5 \times 1.5 \times 1.5$ $\mathrm{cm})$ were measured using the EZ Test-500N texture analyzer (TA-XTZ-5, Shimadzu Co., Japan) equipped with a cylindrical plunger (diameter $5 \mathrm{~mm}$, depression speed 60 $\mathrm{mm} / \mathrm{min}$ ) and a $500 \mathrm{~N}$ load cell. Texture parameters measured included hardness, cohesiveness, springiness, chewiness and adhesiveness.

\section{Sensory evaluation}

Sensory evaluation was performed by 15 panels on the 7 th day of storage. Sausage samples, cut into $2 \mathrm{~cm}$ cubes, were presented to each panelist. The color, aroma, flavor, springiness, juiciness, and overall acceptability were evaluated using a 9-point scale $(1=$ extreme dislikeness, $9=$ extreme likeness).

\section{Statistical analysis}

Measurements of all parameters were performed by 8 replications. All data were analyzed by the general linear model (GLM) of SAS (version 9.1), and the post-hoc test was performed using Duncan's multiple rage test with $\mathrm{p}<0.05$ as the minimum acceptable probability for differences between means.

\section{RESULTS}

\section{Total phenolic and flavonoid content}

Total phenolic and flavonoid contents in AJNE were measured to be $25.38 \pm 0.02 \mathrm{CE} \mu \mathrm{g} / \mathrm{mg}$ and $26.27 \pm 3.95 \mathrm{QE}$ $\mu \mathrm{g} / \mathrm{mg}$, respectively (Table 2 ).

\section{Sausage color}

A significant decrease in the color CIE $\mathrm{L}^{*}$ values of sausage containing ascorbic acid, AJNE and ascorbic acid plus AJNE was observed when compared with control sausage after being stored for $7 \mathrm{~d}(\mathrm{p}<0.05)$ (Table 3$)$.

Table 2. Total phenolic and flavonoid content in water extracts of Achyranthes japonica Nakai

\begin{tabular}{lcc}
\hline & $\begin{array}{r}\text { Total phenolic content } \\
(\mathrm{CE} \mathrm{ug} / \mathrm{mg} \text { extract })\end{array}$ & $\begin{array}{c}\text { Flavonoid content } \\
\text { (QE ug/mg extract) }\end{array}$ \\
\hline A. japonica Nakai & $25.38 \pm 0.02$ & $26.27 \pm 3.95$ \\
\hline $\mathrm{n}=3$, All values are mean \pm standard deviation. &
\end{tabular}


Table 3. Color of sausages containing Achyranthes japonica Nakai

\begin{tabular}{lcccc}
\hline & CIE L* $^{*}$ & $\mathrm{a}^{*}$ & $\mathrm{~b}^{*}$ & $\mathrm{~W}$ \\
\hline $\mathrm{CON}^{1}$ & $81.38 \pm 0.46^{\mathrm{A}}$ & $6.53 \pm 0.64^{\mathrm{B}}$ & $7.79 \pm 0.41^{\mathrm{B}}$ & $58.01 \pm 1.22^{\mathrm{A}}$ \\
$\mathrm{T} 1$ & $80.64 \pm 0.37^{\mathrm{B}}$ & $7.71 \pm 0.33^{\mathrm{A}}$ & $7.83 \pm 0.19^{\mathrm{B}}$ & $57.14 \pm 0.66^{\mathrm{B}}$ \\
$\mathrm{T} 2$ & $80.71 \pm 0.43^{\mathrm{B}}$ & $6.52 \pm 0.66^{\mathrm{B}}$ & $7.40 \pm 0.53^{\mathrm{A}}$ & $55.51 \pm 1.70^{\mathrm{C}}$ \\
$\mathrm{T} 3$ & $80.44 \pm 0.34^{\mathrm{B}}$ & $7.37 \pm 0.39^{\mathrm{A}}$ & $7.91 \pm 0.30^{\mathrm{B}}$ & $56.71 \pm 0.95^{\mathrm{B}}$ \\
\hline
\end{tabular}

${ }^{1}$ CON: no ascorbic acid and AJNE; T1: 0.05\% ascorbic acid; T2: 0.05\% AJNE, T3: 0.05\% ascorbic acid plus 0.05\% AJNE.

A-C Means \pm SD are significantly different within the same column $(\mathrm{p}<0.05)$.

Whereas, an increase in CIE a* values in ascorbic acid and ascorbic acid plus AJNE added-sausages was observed. However, addition of $0.05 \%$ AJNE into pork sausage had no effect on $a^{*}$ value; whereas a significant increase in $b^{*}$ value was observed. The whiteness ( $\mathrm{W}$ value) was also significantly lower among treatments due to the addition of AJNE in pork sausages $(\mathrm{p}<0.05)$.

\section{Non-heme iron value}

Non-heme iron concentrations in cooked sausages are shown in Figure 1. Non-heme iron concentrations in sausages were found to range from 0.073 to $0.079 \mathrm{mg} / 100 \mathrm{~g}$. The highest value of non-heme iron was observed in control group $(0.079 \mathrm{mg} / 100 \mathrm{~g})$ when compared with ascorbic acid group $(0.074 \mathrm{mg} / 100 \mathrm{~g})$, AJNE group $(0.075 \mathrm{mg} / 100 \mathrm{~g})$ and ascorbic acid plus AJNE group $(0.073 \mathrm{mg} / 100 \mathrm{~g})(\mathrm{p}<0.05)$.

\section{POV value}

The differences in POV amongst different treatments are shown in Figure 2. After $7 \mathrm{~d}$ of storage, POV value of sausage with AJNE was $3.35 \mathrm{meq} / \mathrm{kg}$ and showed lower value than control sausage $(3.78 \mathrm{meq} / \mathrm{kg}) \quad(\mathrm{p}<0.05)$.

\section{Non-heme iron (mg/100 g)}

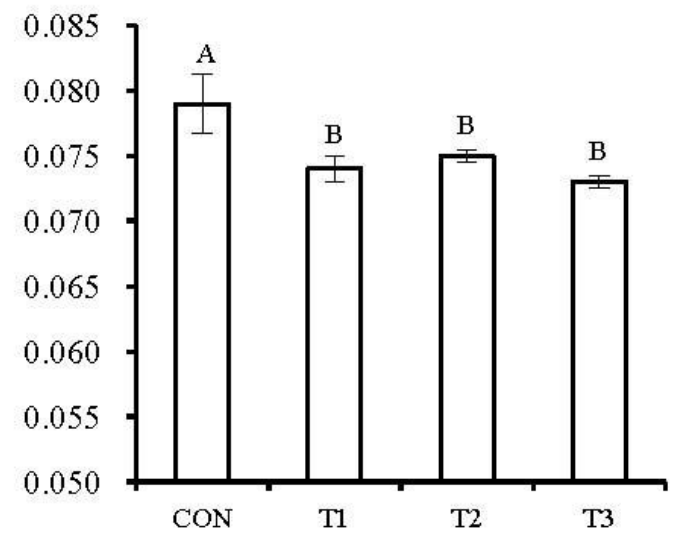

Figure 1. Non-heme iron content in sausages containing Achyranthes japonica Nakai. ${ }^{1} \mathrm{CON}$ : no ascorbic acid and AJNE; T1: $0.05 \%$ ascorbic acid; T2: $0.05 \%$ AJNE; T3: $0.05 \%$ ascorbic acid plus $0.05 \%$ AJNE. ${ }^{\text {A-B }}$ Means \pm SD with the different letters are significantly different $(\mathrm{p}<0.05)$.

\section{POV (meq/kg)}

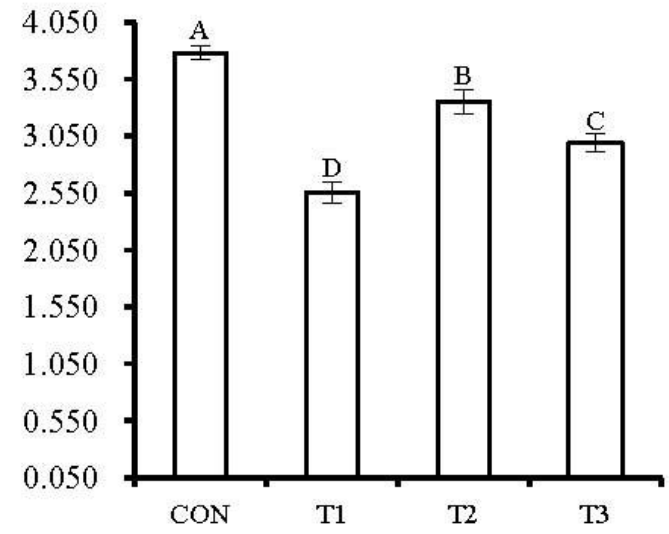

Figure 2. POV of sausages containing Achyranthes japonica Nakai. ${ }^{1}$ CON: no ascorbic acid and AJNE; T1: $0.05 \%$ ascorbic acid; T2: $0.05 \%$ AJNE; T3: $0.05 \%$ ascorbic acid plus $0.05 \%$ AJNE. ${ }^{A-D}$ Means \pm SD with the different letters are significantly different $(\mathrm{p}<0.05)$.

Significant differences were also observed in ascorbic acid group $(2.55 \mathrm{meq} / \mathrm{kg}$ ) and ascorbic acid plus AJNE group $(2.99 \mathrm{meq} / \mathrm{kg})(\mathrm{p}<0.05)$. The evaluated POV value of the four different treatments was in the order; control $>\mathrm{T} 2>\mathrm{T} 3>\mathrm{T} 1$.

\section{Residual nitrite value}

Residual nitrite of approximately $60.7 \mathrm{ppm}$ was found in the sausage of the control group (Figure 3). The addition of ascorbic acid and ascorbic acid plus AJNE into sausages let to a significant decrease (32.4 and $49.9 \mathrm{ppm}$, respectively) in residual nitrite level $(\mathrm{p}<0.05)$. Addition of $0.05 \%$ AJNE (57.59 ppm) had no effect on the residual

\section{Residual nitrite (ppm)}

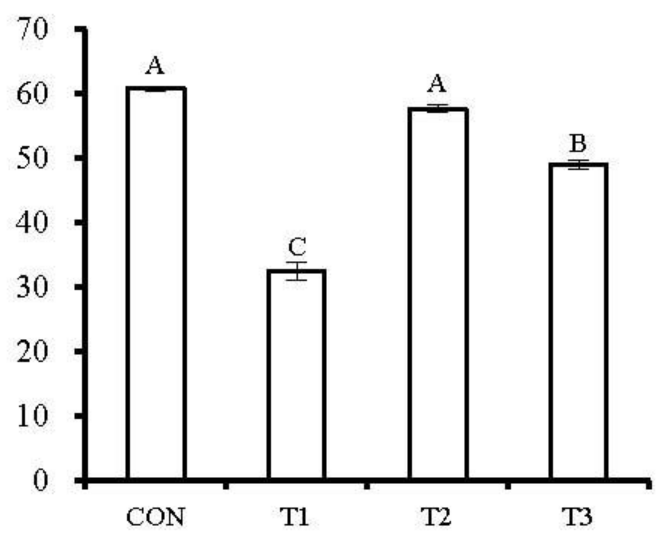

Figure 3. Residual nitrite concentration in sausages containing Achyranthes japonica Nakai. ${ }^{1} \mathrm{CON}$ : no ascorbic acid and AJNE; T1: $0.05 \%$ ascorbic acid; T2: 0.05\% AJNE; T3: 0.05\% ascorbic acid plus $0.05 \%$ AJNE. ${ }^{\text {A-C }}$ Means \pm SD with the different letters are significantly different $(\mathrm{p}<0.05)$. 


\section{Nitrosomyoglobin (mg/kg)}

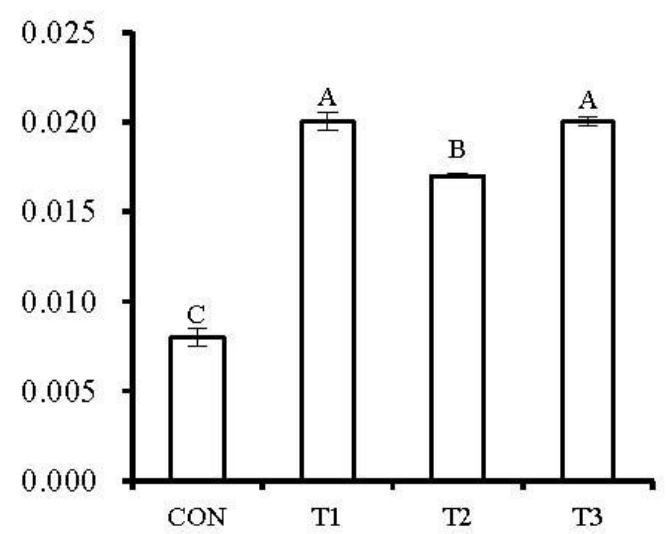

Figure 4. Nitosomyoglobin content in sausages containing Achyranthes japonica Nakai. ${ }^{1} \mathrm{CON}$ : no ascorbic acid and AJNE; T1: $0.05 \%$ ascorbic acid; T2: $0.05 \%$ AJNE; T3: $0.05 \%$ ascorbic acid plus $0.05 \%$ AJNE. ${ }^{\text {A-C }}$ Means \pm SD with the different letters are significantly different $(\mathrm{p}<0.05)$.

nitrite level of pork sausages.

\section{Nitrosomyoglobin value}

The nitrosomyoglobin content in all the treatments $(0.02$, 0.017 and $0.02 \mathrm{mg} / \mathrm{kg}$ in ascorbic acid group, AJNE group and ascorbic acid plus AJNE group, respectively) was increased when compared with the control group $(0.008$ $\mathrm{mg} / \mathrm{kg}$ ), and the highest myoglobin content was observed for the sausage containing ascorbic acid and AJNE plus ascorbic acid $(\mathrm{p}<0.05)$ (Figure 4$)$.

\section{DPPH value}

The DPPH free radical scavenging activity of ascorbic acid group and ascorbic acid plus AJNE group was $34.13 \%$ and $18.37 \%$, respectively, and these values were higher than control group, which showed $7.53 \%$ of activity $(\mathrm{p}<0.05)$ (Figure 5). However, no change in the DPPH values was observed for the sausage containing AJNE only.

\section{Texture properties}

The effect of addition of AJNE on texture properties were measured, and the results are provided in Table 4. All profiles (hardness, cohesiveness, springiness, chewiness and adhesiveness) measured were not influenced by the

\section{DPPH (\%)}

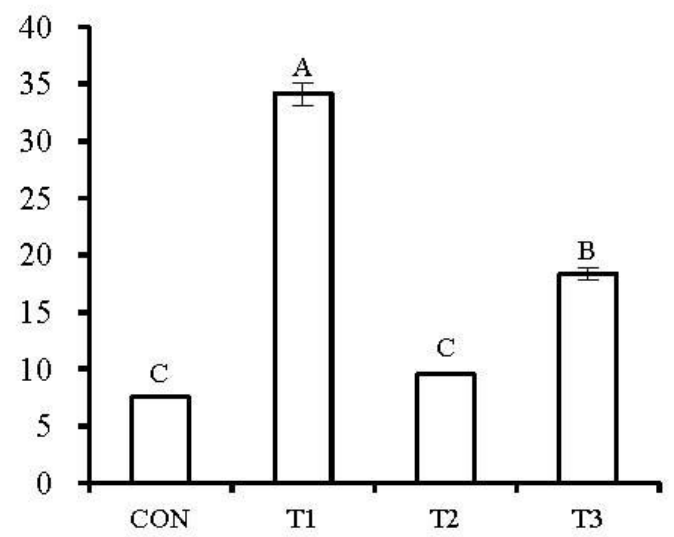

Figure 5. The DPPH free radical scavenging activity of sausages containing Achyranthes japonica Nakai. ${ }^{1} \mathrm{CON}$ : no ascorbic acid and AJNE; T1: 0.05\% ascorbic acid; T2: 0.05\% AJNE; T3: 0.05\% ascorbic acid plus $0.05 \%$ AJNE. ${ }^{\text {A-C }}$ Means \pm SD with the different letters are significantly different $(\mathrm{p}<0.05)$.

addition of AJNE, ascorbic acid and AJNE plus ascorbic acid.

\section{Sensory evaluation}

The influence of AJNE, ascorbic acid and AJNE plus ascorbic acid on sensory evaluation scores of sausages is shown in Table 5. The treatments with ascorbic acid and AJNE plus ascorbic acid had a higher score for internal color than the control and AJNE added-sausages $(p<0.05)$. Aroma, flavor, springiness, juiciness and overall acceptability were not significantly different amongst treatments.

\section{DISCUSSION}

The higher intensity of redness of sausages containing nitrite is due to the fact that nitrite is reduced to nitric oxide (NO) by ascorbic acid, and reacts with myoglobin to form the red nitrosomyoglobin (Adams, 1997). As expected, the sausages produced with ascorbic acid had the highest value for redness, but the presence of AJNE prevented any increase in redness. The whiteness was also significantly low among treatments due to the addition of AJNE in pork sausages. The dark color of AJNE might be responsible for

Table 4. Texture properties of sausages containing Achyranthes japonica Nakai

\begin{tabular}{lcccc}
\hline & $\begin{array}{c}\text { Hardness } \\
(\mathrm{kg})\end{array}$ & $\begin{array}{c}\text { Cohesiveness } \\
(\%)\end{array}$ & $\begin{array}{c}\text { Springiness } \\
(\mathrm{mm})\end{array}$ & $\begin{array}{c}\text { Chewiness } \\
(\mathrm{kg}, \mathrm{mm})\end{array}$ \\
\hline $\mathrm{CON}^{1}$ & $4.30 \pm 1.16$ & $4.45 \pm 1.01$ & $6.25 \pm 1.59$ & $22.20 \pm 5.09$ \\
$\mathrm{~T} 1$ & $4.60 \pm 1.24$ & $4.00 \pm 1.03$ & $6.60 \pm 1.68$ & $26.20 \pm 6.27$ \\
$\mathrm{~T} 2$ & $4.25 \pm 1.40$ & $4.35 \pm 1.36$ & $6.10 \pm 1.29$ & $23.70 \pm 4.99$ \\
$\mathrm{~T} 3$ & $4.40 \pm 1.37$ & $4.35 \pm 1.08$ & $5.85 \pm 1.51$ & $24.60 \pm 5.52$ \\
\hline
\end{tabular}

${ }^{1}$ CON: no ascorbic acid and AJNE; T1: 0.05\% ascorbic acid; T2: 0.05\% AJNE; T3: 0.05\% ascorbic acid plus $0.05 \%$ AJNE. 
Table 5. Sensory evaluation of sausages containing Achyranthes japonica Nakai

\begin{tabular}{lcccccc}
\hline & Color & Aroma & Flavor & Springiness & Juiciness & Overall acceptability \\
\hline $\mathrm{CON}^{1}$ & $6.65 \pm 0.47^{\mathrm{B}}$ & $6.80 \pm 0.54$ & $7.10 \pm 0.39$ & $7.00 \pm 0.33$ & $7.05 \pm 0.44$ & $6.85 \pm 0.47$ \\
$\mathrm{~T} 1$ & $7.60 \pm 0.46^{\mathrm{A}}$ & $7.10 \pm 0.46$ & $7.20 \pm 0.59$ & $6.95 \pm 0.37$ & $7.15 \pm 0.47$ & $7.30 \pm 0.48$ \\
$\mathrm{~T} 2$ & $6.65 \pm 0.47^{\mathrm{B}}$ & $6.85 \pm 0.71$ & $7.10 \pm 0.39$ & $7.00 \pm 0.24$ & $7.05 \pm 0.37$ & $7.05 \pm 0.55$ \\
$\mathrm{~T} 3$ & $7.35 \pm 0.41^{\mathrm{A}}$ & $6.90 \pm 0.46$ & $6.95 \pm 0.60$ & $7.05 \pm 0.16$ & $7.25 \pm 0.26$ & $7.05 \pm 0.60$ \\
\hline
\end{tabular}

${ }^{1} \mathrm{CON}$ : no ascorbic acid and AJNE; T1: 0.05\% ascorbic acid; T2: 0.05\% AJNE; T3: 0.05\% ascorbic acid plus 0.05\% AJNE.

${ }^{\text {A-B }}$ Means \pm SD are significantly different within the same column $(\mathrm{p}<0.05)$.

the negative decrease in $L^{*}$ and $a^{*}$ values, respectively. Interestingly, the results of our study performed with AJNE were similar to the previous reports of Du and Ahn (2002), which reported the decrease in sausage redness between plant extract treatments (e.g. rosemary, sesamol, gallic acid) and control. Moreover, the present findings suggest that AJNE had no direct effect on the improvement of color L*, $\mathrm{a}^{*}$ and $\mathrm{W}$ in comparison with control sausages.

Dietary iron presents as two major forms, heme and non-heme iron (Kongkachuichai et al., 2002). Although plant materials contain only non-heme iron, meat products contain both heme and non-heme iron. Based on the report that ferrous iron in general had a significant effect on the rate at which oxymyoglobin was converted into metmyoglobin (oxdative state of myoglobin) in the absence of lipid (Allen and Cornforth, 2006), high iron ions could induce lipid oxidation. Decreased non-heme iron in this study due to the addition of AJNE may be related to the reduction of myoglobin oxidation in sausage.

An increase in the POV value in sausages was observed with $0.05 \%$ AJNE treatment, showing the same pattern as the non-heme iron values. Currently, there is a lack of useful data regarding the presence of AJNE in sausages, but lipid oxidation reduction could be attributed to the presence of polyphenols, rich in anthocyanins (Yoshida et al., 1999; Han et al., 2005) as well as other saponins, inokosterone, ecdysterone and eleanoic acid bisdesmoside (Hahn and Lee, 1991; Ida et al., 1994) in plant extracts. The finding of the present report is in agreement with the findings of the several other studies, which have reported, the successful inhibition of lipid oxidation in many processed meat products using natural antioxidants of plant origin (Formanek et al., 2003; O'Grady et al., 2008; Nunez de Gonzalez et al., 2008; Devatkal et al., 2010). Another explanation for decrease in POV values in AJNE addedsausages is also possible. The AJN produced in Korea also contains $977 \mathrm{ppm}$ of sulphite (Kim et al., 2000a) which is a food additive used widely in the food industry as a preservative. It might be expected that sulphite in AJN might influence the POV value. These results suggest that $0.05 \%$ AJNE would be sufficient to inhibit the generation of POV, although did not have the same effect as $0.05 \%$ ascorbic acid in cooked pork sausages.
The presence of residual nitrate in the meat products to which only nitrite has been added is attributed to the oxidation of nitrite to nitrate (Honikel, 2008). Kim et al. (2000b), Ha et al. (2001) and Cho et al. (2006) reported that a steady decrease in the nitrite content was observed in meat products produced with plant extract. This could be due to the high reactivity of nitrite, which allowed its reactions with active polyphenols, flavonoids and ascorbic acid present in the plant extract. In the present study, 0.05\% ascorbic acid resulted in significantly lowering residual nitrite. However, the results of AJNE addition were not similar to the reported data, and AJNE had no effect on the residual nitrite concentration in sausages.

It is well known that myoglobin is converted into nitrosomyoglobin during the curing of sausages (Varnam and Satherland, 1995). Ascorbic acid is generally used to increase the rate of conversion, and thus, the formation of nitrosomyoglobin is also increased. The current study identified that the addition of AJNE also influenced the nitrosomyoglobin formation, although AJNE was less effective than ascorbic acid in the rate of conversion.

Previous studies have reported that phenolic compounds in spices and herbs significantly contributed to their antioxidant properties (Shan et al., 2005; Wong et al., 2006; Wu et al., 2006). Similar to these findings, Naveena et al. (2008) reported free radical scavenging activity in juice, extract, seed and powder of certain plants. Jayawardana et al. (2011) have also reported a significant relation between phenolic content and antioxidant effect of plant extracts in pork sausages. Kwon et al. (2008) reported that ANJ root showed relatively high antioxidant activities. However, in this study, DPPH values of AJNE added-sausages were slightly higher but no differences in statistically were observed between the AJNE treatments and control unlike the effect of ascorbic acid.

Rowe et al. (2004) reported that retarded lipid oxidation of muscle fibers was related to textural properties and sensory evaluations of sausage. However, in the present study, the decreased POV values in the sausages with the added AJNE were not closely associated with texture properties. The results also suggested that the addition of ascorbic acid and AJNE plus ascorbic acid in pork sausages resulted in high scores for color value, but addition of 
0.05\% AJNE had no effect on the color, aroma, flavor, springiness, juiciness, and overall acceptability of the sausage. All the sausages were found to be of moderately good overall acceptability. The sausage containing AJNE and control were rated as 6.85 and 7.05 based on overall acceptability respectively, thus indicating that they were moderately good.

\section{CONCLUSIONS}

Ascorbic acid was demonstrated to have an effect on the meat color, non-heme iron, POV, residual nitrite, nitrosomyogloin and DPPH values. The addition of ascorbic acid plus AJNE showed intermediate values in these measurements. Use of AJNE at $0.05 \%$ concentration effectively suppressed the POV increment, and appeared to have an effect on non-heme iron concentration and nitrosomyglobin content in cooked pork sausages. Addition of $0.05 \%$ AJNE in cooked pork sausages resulted in low scores for color values in sensory evaluation, but did not affect other parameters including overall acceptability. Thus, the inclusion of AJNE, as a natural ingredient may offer a natural alternative for cooked pork sausages with nitrite. In future, further research regarding additional alterations in the concentration of AJNE in sausages is needed to improve the quality of product and consumer acceptance.

\section{ACKNOWLEDGEMENT}

The work was supported by the Priority Research Centers Program of the National Research Foundation of Korea (NRF), funded by the Ministry of Education, Science, and Technology (2012-0006683). The authors would also like to thank H. J. Jung, S. Y. Sohn and H. J. Jeong for their technical support.

\section{REFERENCES}

Adams, J. B. 1997. Food additive-additive interactions involving sulphur dioxide and ascorbic and nitrous acids: a review. Food Chem. 59:401-409.

Akowuah, G. A., Z. Ismail, I. Norhayati and A. Sadikun. 2005. The effects of different extraction solvents of varying polarities of polyphenols of Orthosiphon stamineus and evaluation of the free radical-scavenging activity. Food Chem. 93:311-317.

Allen, K. E and D. P. Cornforth. 2006. Myoglobin oxidation in a model system as affected by nonheme iron and iron chelating agents. J. Agric. Food Chem. 54:10134-10140.

AOAC. 2000. Official method of analysis. 17th Edition. Association of Official Analytical Chemists, Washington, DC, USA.

Bozkurt, H and O. Erkmen. 2002. Effects of starter cultures and additives on the quality of Turkish style sausage (sucuk). Meat Sci. 61:149-156.

Carter, P. 1971. Spectrophotometric determination of serum iron at the submicrogram level with a new reagent (ferrozine). Anal. Biochem. 40:450-458.

Cho, S. H., S. A. Jung, E. J. Song, S. Y. Lee, K. B. Kim, W. R. Park, J. G. Park, S. M. Park and D. H. Ahn. 2006. Effect of improvement of storage properties and reducing of sodium nitrate by Glycyrrhiza uralensis and Curcula longa in pork sausage. J. Korean Soc. Food Sci. Nutr. 35:997-1004.

Chouliara, E., A. Karatapanis, I. N. Savvaidis and M. G. Kontominas. 2007. Combined effect of oregano essential oil and modified atmosphere packaging on shelf-life extension of fresh chicken breast meat, stored at 4 degrees C. Food Microbiol. 24:607-617.

Chun, O. K., D. O. Kim and C. Y. Lee. 2003. Superoxide radical scavenging activity of the major polyphenols in fresh plums. J. Agric. Food. Chem. 51:8067-8072.

Cowan, M. M. 1999. Plant products as antimicrobial agents. Clin. Microbiol. Rev. 12:564-582.

Devatkal, S. K, K. Narsaiah and A. Borah. 2010. Anti-oxidant effect of extracts of kinnow rind, pomegranate rind and seed powders in cooked goat meat patties. Meat Sci. 85:155-159.

Du, M and D. U. Ahn. 2002. Effect of antioxidants on the quality of irradiated sausages prepared with turkey thigh meat. Poult. Sci. 81:1251-1256.

Eyiler, E and A. Oztan. 2011. Production of frankfurters with tomato powder as a natural additive. LWT-Food Sci. Technol. 44:307-311.

Formanek, Z., A. Lynch, K. Galvin, J. Farkas and J. P. Kerry. 2003. Combined effects of irradiation and the use of natural antioxidants on the shelf-life stability of over wrapped minced beef. Meat Sci. 63:433-440.

Ha, J. U., Y. K. Ryu and H. J. Park. 2001. Nitrite scavenging ability and antioxidative activity of water extract and ethanol extract from Cassia tora L. and Pueraria thunbergiana. Korean J. Food Sci. Anim. Resour. 21:1-9.

Hahn, D. R. and M. W. Lee. 1991. Studies on the constituents of Achyranthis radix (I) oleanolic acid bisdesmoside from the root. Yakhak Heoji 35:457-460.

Han, S. B., C. W. Lee, Y. D. Yoon, J. H. Lee, J. S. Kang, K. H. Lee, W. K. Yoon, K. Lee, S. K. Park and H. M. Kim. 2005. Prevention of arthritic inflammation using an oriental herbal combination BDX-1 isolated from Achranthes bidentata and Atractylodes japonica. Arch. Pharm. Res. 28:902-908.

Honikel, K. O. 2008. The use and control of nitrate and nitrite for the processing of meat products. Meat Sci. 78:68-76.

Ida, Y., M. Katsumata, Y. Satoh and J. Shoji. 1994. Glucuronide saponins of oleanolic acid from Achyranthes fauriei roots. Planta. Med. 60:286-287.

Jayawardana, B. C., T. Hirano, K. H. Han, H. Ishii, T. Okada, S. Shibayama, M. Fukushima, M. Sekikawa and K. Shimada. 2011. Utilization of adzuki bean extract as a natural antioxidant in cured and uncured cooked pork sausages. Meat Sci. 89:150-153.

Jin, S. K., Y. J. Kim, J. H. Park, I. C. Hur, S. H. Nam and D. Shin. 2012. Effects of purple-fleshed sweet potato (Ipomoera batatas Cultivar Ayamurasaki) powder addition on color and texture properties and sensory characteristics of cooked pork sausages during storage. Asian-Aust. J. Anim. Sci. 25:13291337.

Jung, S. M., S. I. Choi, S. M. Park and T. R. Heo. 2007. 
Antimicrobial effect of Achyranthes japonica Nakai extracts against Clostridium difficile. Korean J. Food Sci. Technol. 39:564-568.

Kim, C. M., B. J. Song and H. S. Na. 2000a. Determination of sulfite contents in medical herbs. J. Korean Soc. Food Sci. Nutr. 29:375-379.

Kim, S. M., Y. S. Cho, R. M. Yang, S. H. Lee, D. G. Kim and S. K. Sung. 2000b. Development of functional sausage using extracts from Schizandra chinensis. Korean J. Food Sci. Ani. Resour. 20:272-281.

Kong, B., J. Wang and Y. L. Xiong. 2007. Antimicrobial activity of several herb and spice extracts in culture medium and in vacuum-packaged pork. J. Food. Prot. 70:641-647.

Kongkachuichai, R., P. Napatthalung and R. Charoensiri. 2002. Heme and nonheme iron content of animal products commonly consumed in Thailand. J. Food Compos. Anal. 15:389-398.

Kwon, J. W., E. J. Lee, Y. C. Kim, H. S. Lee and T. O. Kwon. 2008. Screening of antioxidant activity from medicinal plant extracts. Korean J. Pharmacogn. 39:155-163.

Marcone, M. F, F. Jahaniaval, H. Aliee and Y. Kakuda. 2003. Chemical characterization of Achyranthes bidentata seed. Food Chem. 81:7-12.

Martin-Diana, A. B., D. Rico and C. Barry-Ryan. 2008. Green tea extract as a natural antioxidant to extend the shelf-life of freshcut Lettuce. Innov. Food Sci. Emerg. Technol. 9:593-603.

Medina, I., M. J. Gonza'lez, M. Pazos, D. D. Medaglia, R. Sacchi and J. M. Gallardo. 2003. Activity of plant extracts for preserving functional food containing n-3 PUFA. Eur. Food Res. Technol. 217:301-307.

Naveena, B. M, A. R. Sen, R. P. Kingsly, D. B. Singh and N. Kondaiah. 2008. Antioxidant activity of pomegranate rind powder extract in cooked chicken patties. Int. J. Food. Sci. Tech. 43:1807-1812.

Nunez de Gonzalez, M. T., R. M. Boleman, R. K. Miller, J. T. Keeton and K. S. Rhee. 2008. Antioxidant properties of dried plum ingredients in raw and precooked pork sausage. J. Food Sci. 73:H63-71.

O’Grady, M. N., R. Carpenter, P. B. Lynch, N. M. O’Brien and J. P. Kerry. 2008. Addition of Grape seed extract and bearberry to porcine diets: Influence on quality attributes of raw and cooked pork. Meat Sci. 78:438-446.

Park, J. W. 2005. Codex code for frozen surimi. In: Surimi and Surimi Seafood, Boca Raton: Taylor and Francis Group (Ed. J. W. Park), 869-885.
Rounds, L., C. M. Havens, Y. Feinstein, M. Friedman and S. Ravishankar. 2012. Plant extracts, spices, and essential oils inactivate Escherichia coli $0157: \mathrm{H} 7$ and reduce formation of potentially carcinogenic heterocyclic amines in cooked beef patties. J. Agric. Food Chem. 60:3792-3799.

Rowe, L. J., K. R. Maddock, S. M. Lonergan and E. HuffLonergan. 2004. Oxidative environments decrease tenderization of beef steaks through inactivation of $\mu$-calpain. J. Anim. Sci. 82:3254-3266.

Shan, B., Y. Z. Cai, M. Sun and H. Corke. 2005. Antioxidant capacity of 26 spice extracts and characterization of their phenolic constituents. J. Agric. Food Chem. 53:7749-7759.

Singleton, V. L. and J. A. Rossi. 1965. Colorimetry of total phenolics with phosphomolybdic-phosphotungstic acid reagent. Am. J. Enol. Viticult. 16:144-158.

Tanabe, H., M. Yoshida and N. Tomita. 2002. Comparison of the antioxidant activities of 22 commonly used culinary herbs and spices on the lipid oxidation of pork meat. Anim. Sci. J. 73:389-393.

Torres, J. L., B. Varela, M. T. Garcı'a, J. Carilla, C. Matito, J. J. Centelles, M. Cascante, X. Sort and R. Bobet. 2002. Valorization of grape (Vitis vinifera) byproducts. Antioxidant and biological properties of polyphenolic fractions differing in procyanidin composition and flavomol content. J. Agric. Food Chem. 50:7548-7555.

Varnam, A. and J. Sutherland. 1995. Meat and meat products. London: Chapman and Hall. p. 430.

Wojdylo, A., J. Oszmiański and R. Czemerys. 2007. Antioxidant activity and phenolic compounds in 32 selected herbs. Food Chem. 105:940-949.

Wong, C. C., H. B. Li, K. W. Cheng and F. Chen. 2006. A systematic survey of antioxidant activity of 30 Chinese medicinal plants using the ferric reducing antioxidant power assay. Food Chem. 97:705-711.

Wu, C. Q., F. Chen, X. Wang, H. J. Kim, G. Q. He, V. Haley-Zitlin and G. Huang. 2006. Antioxidant constituents in feverfew (Tanacetum parthenium) extract and their chromatographic quantification. Food Chem. 96:220-227.

Yoshida, H., T. Ishikawa, H. Hosoai, M. Suzukawa, M. Ayaori, T. Hisada, S. Sawada, A. Yonemura, K. Higashi, T. Ito, K. Nakajima, T. Yamashita, K. Tomiyasu, M. Nishiwaki, F. Ohsuzu and H. Nakamura. 1999. Inhibitory effect of tea flavonoids on the ability of cells to oxidize low density lipoprotein. Biochem. Pharmacol. 58:1695-1703. 